\title{
Dynamics of the Natural Gas Industry and Economic Growth in Mozambique
}

\author{
Abdul Gafur Nazordine Mahomed Bay*, Liang Hong \\ School of International Trade and Economics, Jiangxi University of Finance and Economics, Nanchang, People's Republic of China \\ Email address: \\ gafur.bay@hotmail.com (A. G. N. M. Bay), alina6696@163.com (Liang Hong) \\ ${ }^{*}$ Corresponding author \\ To cite this article: \\ Abdul Gafur Nazordine Mahomed Bay, Liang Hong. Dynamics of the Natural Gas Industry and Economic Growth in Mozambique. Science \\ Journal of Energy Engineering. Vol. 5, No. 3, 2017, pp. 68-77. doi: 10.11648/j.sjee.20170503.13
}

Received: April 15, 2017; Accepted: May 4, 2017; Published: October 23, 2017

\begin{abstract}
This paper investigates dynamics of the natural gas industry and economic growth in Mozambique for the period of 1999 to 2015. Times series data is collected from Index Mundi, produced by World Bank and it includes export and labor. This study employs Error Correction model. Results report that the natural gas industry, export, and labor are positively cointegrated with economic growth, and they have a long-run relationship. In a short-run term, results revealed that the natural gas industry has a positive effect and it is significant to influence economic growth in Mozambique. However, on the other hand, export and labor contribution to economic growth is small. The study recommends that government should implement a growth policy for the natural gas industry because it would stimulate economic growth. In Mozambique, the natural gas industry will experience foremost dynamics with the production of natural gas in Rovuma Basin scheduled to start by 2022, and it will play a great role to promote the economic growth in the upcoming future.
\end{abstract}

Keywords: Natural Gas Industry, Economic Growth, Rovuma Basin Natural Gas, Error Correction Model, Mozambique

\section{Introduction}

Energy is a vital source of economy growth because many production and consumption activities involve energy as a required input [35]. Due to its key role in economic growth, it is important to diversify sources of energy as clean as possible for strategic, environmental and energy security reasons [15]. Since the beginning of the use of natural gas as a source of electricity and the oil shock back in 1970's, natural gas has not ceased to assert itself as a privileged primary energy source, constituting currently a compelling alternative to oil, with similar importance to nuclear energy and renewable energies [52]. Furthermore, natural gas has become attractive energy source due to its advantages: it is environmentally friendly because of less carbon dioxide $\left(\mathrm{CO}_{2}\right)$ emissions compared to coal and oil, and it has also fewer pollutants [58]. These advantages are attracting many countries to use natural gas as an alternative source of energy generation and in line with Kyoto Protocol requirements [5].

Natural gas occupies the second position in the world energy matrix with a $15.6 \%$ share of total primary energy demand, behind only oil, which has the largest share, accounting for $41.6 \%$ of total energy consumption in the world [14]. Natural gas consumption is expected to growth at $18 \%$ annually until 2035 [60]. Only one-third of natural gas is traded across borders compared with two-third of oil because of its high costs of transportation. Differently from oil that has a global market, natural gas does not have a world market but rather regional markets. Therefore, natural gas does not behave like a commodity because prices around the world are different. In the United States of America, Great Britain and Australia prices are set through market competition. However, in former countries of Union of Soviet Socialist Republics and the European Union markets, it is transported through pipelines and sold in long-term contracts by Russia. These characteristics associated with the structure of supply and demand of the product are influencing natural gas prices in these regions $[65,66,67]$.

Recently in Mozambique was discovered an enormous amount of natural gas estimated at 190 trillion cubic feet (Tcf) of natural gas in the Rovuma Basin, north of the country [43]. Mozambique will have the fourth natural gas 
reserve in the world after Russia, Iran, and Qatar; and its position along the Indian Ocean is an advantage to access the world's Liquefied Natural Gas (LNG) market of East and Southeast Asia, through maritime route [21]. For this reason, Mozambique is set to become a world-class natural gas exporter with projections indicating that it will experience a rapid increase in revenues over the next decades and well beyond [11]. The volume of natural gas discovered in the Rovuma Basin bring opportunities for the development of high impact socio-economic programs in the country, that would lead to alleviate Mozambique's economy hardship thus raising the population's standard of living. Like many African developing nations, Mozambique is a country handicapped by poor infrastructure, inadequate education, and rampant corruption. In 2016 Mozambique recorded an economic growth of only $3.3 \%$ dropping down from $6.6 \%$ registered in 2015; and the Foreign Direct Investment (FDI) reduced in $20 \%$ indicating a break of confidence from foreign investors; a contrasting average economic growth of 7.5 percent revealed during the last 15 years (2000 to 2014), which was based on massive investments in agro-industry, agriculture, tourism, fishing, and mining [68].

In Africa, natural resources such as oil and diamonds have been at the center of discussions about how governments should apply the revenue of these resources for the benefit of their populations through promoting economic growth. In one side, Botswana is a prosperous country that through exploration of natural resources is boosting economic growth by investing in public infrastructure and also a strong Social Security system. At other, countries like Nigeria, Angola, Sudan, Sierra Leone, Liberia and Democratic Republic of Congo (DRC), serve as negative examples; they are all gifted with considerable natural resources, but they have been less successful in using their endowments to make the transition from underdeveloped to developed countries [13, 27, 29].

In fact, before the $1980 \mathrm{~s}$ the conventional wisdom advocates that natural resource abundance has positive effects on economic growth [53]. In line with this perspective, natural resource wealth is a blessing to promote economic growth; revenues obtained from natural resource are used to invest in other sectors of the economy helping countries to transit from the stage of underdevelopment to developed nations as occurred in the USA, Britain, and Australia; and moreover, the increase of foreign reserves can be seen as a costly self-insurance strategy to lessen vulnerability impact of domestic and foreign shocks and to intervene in the foreign market [1, 22]. Empirical studies providing support for this perspective can be found in the studies of Brunnschweiler and Bulte (2008), and Brunnschweiler (2009), among others [1].

Nonetheless, after the 1980s the assumption that natural resource abundance is a blessing to promote economic growth has been questioned because several natural resource rich countries failed to succeed; an abundance of natural resources can lead to adverse economic consequences. Socioeconomic phenomena such as resource curse; Dutch disease; revenue volatility; irrational and emotional behavior of the elite which promotes poor resource management; and rentseeking political actors that use natural resource wealth for own benefit promote a negative economic growth, inflation, low savings, high unemployment, exports earning instability, corruption, poverty, and low level of human developments and these occurrences are caused by; and empirical studies affording support of this perspective are found in the works of Mauro (1995); Leite \& Weidmann (1999); Lane \& Tornell (1996); and Tornell \& Lane (1999), among others. [17, 53]. African countries gifted with natural resources such as Angola, Nigeria, and Serra Leone have experienced civil wars not because natural resources provide a source of finance for rebel groups but because of the weakness of the state to effectively repress an occurrence of armed resurrection [18].

In an economic perspective, natural resource is seen as an asset because it is extracted and not produced. Therefore, the generation of natural process wealth can happen separately from other economic and political processes inside a country and this characteristic lead politicians and private sector to use a political mechanism to capture these rents [41]. Even more, governments uses natural resources to fund its own particular interests or of certain groups, such as those who support the government; and in consequence it may cause feelings of injustice and disputes between several groups willing to win their share of the natural resource exploitation; and sometimes this fight between groups may undermine political stability, as is the case of Nigeria [13]. The other challenge that natural resources bring in developing nations is the different capabilities between the government of the resource rich country and MNE because the exploration of natural resources is high intensive capital and technology [41]. For these reasons, researchers present a set of principles that resource rich country government should adopt to ensure that natural resources contribute significantly to economic growth reducing poverty and these policies include (i) avoiding haste, make sure that the country is ready for the exploration of natural resource in terms of the existence of a strong legal framework and robust institutions; (ii) all stages and procedures of the process regarding the exploration of natural resources should be transparent, since bidding, negotiating, licensing, contracting, signing of agreements with MNE including information of volumes extracted, prices of the products, and revenue collected [13, 41, 44]. In fact, good governance and stronger democratic institutions improve resource boom management [4].

At the other hand, it is important to notice that the exploration of natural gas should be done in a sustainable development process, and this goal requires transparent governance and active public engagement to create an environment of understanding and commitment between citizens and government; and it is a long term, never ending process [32]. Mozambique has some of the underlying political and legislative conditions for extraction of natural gas; however, if it is not managed properly, the production of natural gas will not be an excellent opportunity to boost 
economic growth; on the contrary it will be a source of conflicts [25].

This paper aims to investigate dynamics of the natural gas industry and economic growth in Mozambique for the period of 1999 to 2015. It also attempts to find out the existence of long-run relationship between natural gas industry and economic growth. This work presents following structure: 1 . Introduction; 2. Background of the Natural Gas Industry in Mozambique; 3. Literature Review of previous studies; 4. Methodology; 5. Empirical Results; and 6. Conclusion.

\section{Background of the Natural Gas Industry in Mozambique}

Natural gas industry in Mozambique is recent; however, hydrocarbon research dates back to 1948 (still under Portuguese colonialism) when Multinational Enterprises (MNE) Gulf Oil and Pan-American had a strong presence in the country, specifically at the mouth of Save River. As a result, natural gas deposits were discovered in Pande (1961), Búzi (1962) and later in Temane (1967) fields, in Inhambane province, south of the country. Nonetheless, natural gas research was interrupted due to the evolution of national liberation war [62], and later after the independence, which occurred on June 1975, Mozambique was devastated by a civil war that lasted 16 years, which made it impossible to continue with natural gas exploration in the country.

Only in 2004, after an intensive research carried out by Suid-Afrikaanse Steenkoolen Olie (Sasol), a South African company, the first large-scale commercial production gas project was implemented in the south of Mozambique, in the township of Temane followed by Pande in 2008. The business viability of gas reserves in this project is around 2.7 Tcf, equivalent to 25 years production [56]. Later in 2012, Sasol increased its production capacity from the previous 120 million gigajoules per year to 183 million [42]. Pande and Temane project includes a central processing plant and an $865 \mathrm{~km}$ underground pipeline which connects Temane to Secunda (Sasol Chemicals treatment plants) in South Africa. However, the domestic consumption of natural gas is far to have a significant increase in Mozambique, even though some projects are trending to attract consumers such as vehicular natural gas and the new thermoelectric power plant for electricity generation in Ressano Garcia. Also, a domestic gas pipeline in Maputo and Marracuene is not yet in operation [40], which will likely to increase the number of consumers of natural gas.

Later in the years 2010 and 2011, large amounts of natural gas were discovered in the Rovuma Basin, north of Mozambique. Anadarko, an American company, announced the discovery of $85 \mathrm{Tcf}$ in area 1 of Rovuma Basin. On the other side, Ente Nazionale Idrocarburi SpA (ENI), an Italian company, which is exploring area 4, also announced significant natural gas discoveries and determined that Rovuma natural gas, is of high commercial value [39].
Mozambique has about 190 trillion cubic feet (Tcf) of gas, which makes the country one of largest gas producers in the world [43]. Many natural gas discoveries in Rovuma Basin made to date are among the world's most significant developments in the last 20 years. It places Mozambique in the top ten countries with the most natural gas reserve in the world, and it brings opportunities for the development of high impact socio-economic programs in the country that would lead to alleviate Mozambique's economy hardship [3].

Natural gas discoveries in Rovuma Basin could earn Mozambique billions of dollars in FDI and export revenues [27]. Anadarko plans to invest 1.8 billion USD to the targeted start of LNG production by 2018 and a further 90 billion USD in the coming years, and the projected construction of LNG facilities in the country makes it clear that these companies have high expectations and it would be the second largest LNG plant in the world after Qatar [29, 57]. The offshore nature and geographic location of Rovuma Basin make it economically feasible to liquefy and transport it to South and East Asian countries in which the demand for natural gas has been growing fast [38]. Along the coast of Mozambique, there are other areas with the ongoing grind of exploration projects of hydrocarbons, as illustrated in figure 1.

\section{Literature Review}

This section presents a breakdown of existent literature review on dynamics between natural gas and economic growth, and this study adopts the classification of [19], who provides results analysis completed on three different categories: country analysis versus panel data analysis; developed against developing and transition countries; and bivariate set against multivariate approaches.

\subsection{Specific Country Data Analysis vs. Panel Data Analysis}

Relatively to specific studies, [58] inspect the dynamic relationship between natural gas and economic growth for 1972-2012, using Autoregressive distributed lag (ARDL) approach and they observe bi-directional causality between economic growth and natural gas. However, others researchers in Pakistan report different findings detected by [58]. [6] exploring the causal relationship between GDP and energy consumption (oil, gas, and electricity) for 1955-1996, employing Granger causality (GC) test, they do not detect any causal relationship between GDP and natural gas. [61] for the period of 1971-2003 added more variables to control the changes in primary factors of production (labor, capital, human capital formation, and exports), also using GC and ARDL tests and witness the non-causal relationship between GDP and natural gas. Additional other specific studies carried out by [60] and [33] in Pakistan report different results from other researchers because they notice unidirectional causality running from natural gas consumption to economic growth which means that natural gas can contribute to economic growth. 


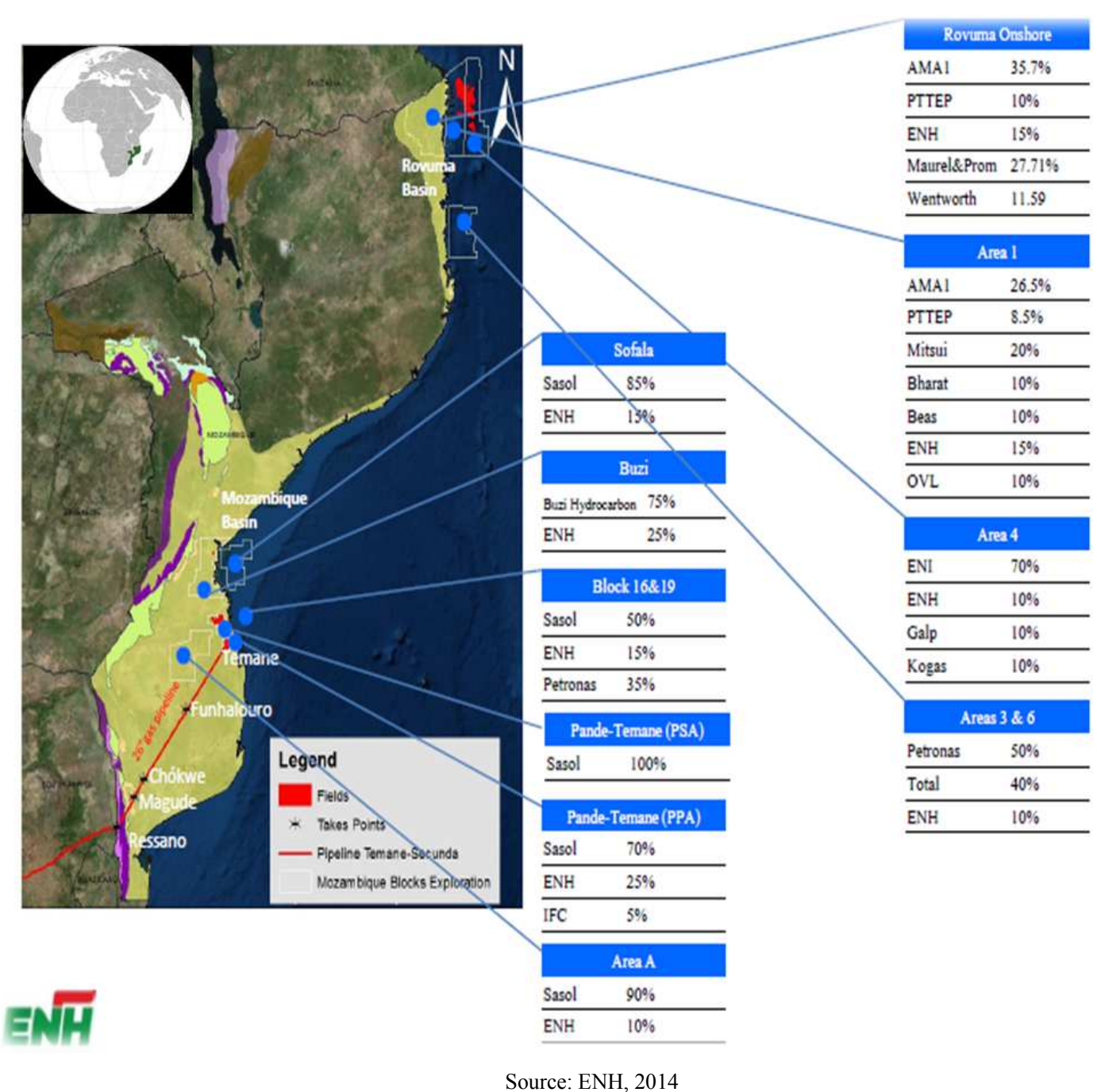

Aug 2014

Figure 1. Mozambique Natural Gas Projects.

For Taiwan [16] investigate the causal relationship between energy consumption and economic growth and between energy and employment for 1995 to 1993, employing Hsiao's version of the GC test and report unidirectional causality running from GDP to energy consumption, which means that increasing economic growth requires high consumption of energy. Trying to check [16] findings, [69] re-examine the causality energy consumptionGDP using times series of 1954-1997, and included aggregate and disaggregate categories of energy consumption (coal, oil, natural gas, and electricity), he discover a bidirectional causality between total energy consumption and GDP and also a unidirectional causality running from natural gas consumption to GDP. The differences in findings are the result of the sample period and variables used [69]. A parallel result of Taiwanese researcher [69] was observed by [35] investigating the relationship between energy consumption and GDP for the period 1954-2003 in Taiwan; also using aggregate and disaggregate categories of energy consumption and Johansen's maximum likelihood and Weak exogeneity tests and he reveals a unidirectional causality running from natural gas consumption to economic growth. On the contrary, [30] undertook an advanced times series method offered by Hansen and Seo (2002), and used Vector error correction method (VECM) to investigate the non-linear cointegration concerning energy consumption and GDP in Taiwan for 1982-2006 and results confirm, at one side, the non-linear long-run relationship between GDP and disaggregated energy consumption in the island, and at other, indicate bidirectional causality between GDP and natural gas. Researchers in Iran examined natural gas consumptioneconomic growth nexus from various perspectives and observed different results. On the one hand, [28] and [70] report bidirectional causality between natural gas consumption and economic growth. [7]; [9] and [37] found a unidirectional causality running from economic growth to natural gas consumption in the same country.

Regarding panel data analysis, a recent study was carried out by [26] examining the relationship between natural gas and economic development in China and Japan for 19802012 and report the existence of a long-run relationship between natural gas and economic growth in both countries. 
[63] do not observe any evidence of feedback relation between natural gas consumption and economic growth in 12 OPEC members, for the period of 1980-2012, but results are different when examining countries individually. [12] report a different result in a group of countries analyzing the same topic for the countries Brazil, Russian, India, China, Turkey and South Africa over 1980-2011 using GC and ARDL methods found causality relationship between natural gas consumption and economic growth only for Brazil, Russia, and Turkey. [34] scrutinize the connection between natural gas and economic development in G-7 countries (Canada, France, Germany, Italy, Japan, United Kingdom-UK, and the USA) using a bootstrap - corrected causality test; they concluded that for the UK there is only a unidirectional causality running from economic growth to natural gas consumption while for Italy is contrary; for Germany, France, and the USA there is a bidirectional causality; for Japan and Canada, there is no any causality. [48] investigate the same correlation in Spain, Romania, and EU for the period 19902010, applying GC test; and they report a long-run relationship between GDP per capita and energy consumption with source natural gas for Spain and Romania; and for EU was only discovered a long-run relationship proven among GDP per capita and energy consumption with source renewable and total petroleum products. [5] examining natural gas consumption and economic growth nexus for a panel of 67 countries for the period 1992-2005, employing Pedroni panel cointegration and GC causality test, report bidirectional causality between natural gas consumption and economic growth in both short and longrun. By the other side, [8] for five South Asian countries (India, Pakistan, Sri Lanka, Bangladesh and Nepal) over 1971-2003, using Toda and Yamamoto approach, observed that only for Bangladesh there is a unidirectional causality running from natural gas consumption to economic growth, but for Pakistan, India, Sri Lanka and Nepal there is no causality. [20] investigating OECD countries for the period 1991-2013, used VECM and report bidirectional causality between natural gas consumption and economic growth in these countries.

\subsection{Developed vs. Developing and Transition Countries}

[59] investigate the natural gas consumption and economic growth nexus in France for the period of 1970-2010, adding other variables (exports, capital, and labor), using ARDL method and report a unidirectional causality running from natural gas consumption to economic growth. [47] employed Toda and Yamamoto causality test to analyze the relationship between natural gas consumption and economic growth in the USA for the period of 1949-2006 and discovered a unidirectional causality running from natural gas consumption to economic growth. The result reported by [47] is similar to that identified by [23] on the same topic in the USA for 2001-2005 even though using monthly data and generalized forecast error variance and GC test. A parallel result was also reported by [55] for the same country and for the period 2001-2005 employing VECM and ARDL models.
[50] study the natural gas consumption and economic growth nexus in the USRR for the period of 1928-2003, using GC test and observed a unidirectional causality running from natural gas consumption to economic growth. In a different country, [49] applied Bayer-Hank and Johansen cointegration tests and ARDL approach inspecting the relationship between economic growth and natural gas consumption in Malaysia from 1971 to 2012, and they report a unidirectional causality running from economic growth to natural gas consumption. However, [64] used a similar period and methodology for Malaysia and adding FDI, capital, and trade openness variables; and witnessed bidirectional causality between natural gas consumption and economic growth in Malaysia. In another Asian country, [36] discovered bidirectional causality between natural gas consumption and economic growth in Korea for the period 1991-2008, using GC and Johansen's maximum likelihood tests.

In the north of Africa, [24] surveyed the impact of natural gas consumption, capital and trade on economic growth in Tunisia for 1980-2010, running ARDL and Toda-Yamamoto tests; they observed bi-directional causality between economic growth and natural gas consumption. Nevertheless, in Nigeria, an African country rich in oil and member of OPEC countries, [45] surveyed the natural gas economic growth nexus for the period of 1970-2011 employing VECM model and reported a unidirectional relationship running from GDP to natural gas. This result is similar to that concluded by [46] for the same country for the period of 1975-2010, using GC test.

\subsection{Bivariate vs. Multivariate Approaches}

Researchers choose to do their studies either following a bivariate or a multivariate study. Bivariate studies look strictly at the time series of natural gas consumption and economic growth while multivariate studies also include times series of other control variables. Researchers such as [9] and [70] for Iran; [35] and [30] for Taiwan; [50] in the Former Soviet Union; and [36] for Korea; they all examine natural gas consumption-economic growth nexus using a bivariate approach focusing only on data related to key variables. [60] survey the relationship between natural gas consumption and economic growth in Pakistan for the period 1972-2010 including capital, export, and labor and found that economic growth is expounded strongly by natural gas consumption and capital while the contribution of exports and employment is small. By the other side, [55] analyzed natural gas consumption-economic growth nexus in the USA for the period of 2001-2005 adding labor force and discovered that it does not have an impact on natural gas consumption in short and long term in the country. [5] examine the connection between natural gas consumption and economic growth for a panel of 67 countries for the period 1992-2005, including in the study labor and capital formation; and they report that these variables have significant impact on economic growth; while impact of labor on natural gas consumption is not significant. Natural 
gas consumption has not also a significant impact on real gross fixed capital.

In summary, this paper agrees with the report that research findings on the dynamics of natural gas and economic growth are a lack of consensus because countries are at different stages of development and also due to differences in the data used by researchers $[23,55]$.

\section{Methodology}

This study uses secondary annual data from 1999 to 2015 , retrieved from Index Mundi, produced by World Bank; and it covers the period of 1999 to 2015. Data correspond only to 17 observations, and for this reason, this research employ interpolation method developed by Goldstien \& Khan (1976), which allow getting 60 quarterly observations for reliable results. This study follows a two-step approach: first times series data is inspected if it has unit root using Augmented Dickey-Fuller (ADF) test, which is the most extensively used test among researchers because of its simplicity [54]. ADF test null hypothesis supports the existence of unit root, and the probability of obtaining nonstationary series is high, therefore we shall have to test again but on the first difference which would change the series integrated of order
$1 \mathrm{I}(1)$; and if the series remain nonstationary we will have to apply second differences, which would transform the original series in I(2), or integrated two times [48]. Second, Error Correction Model (ECM) is employed to check dynamic relationship among variables because data is both integrated and stationary and this model can better estimate short and long-run effects and also it is easy for interpretation [51]. ECM is also a useful model to measure the correction from disequilibrium of the previous period, and it solves problems of spurious regressions because variables are stationary at first difference [10].

ECM formula is:

$$
\Delta \gamma 1=\beta 0+\beta \Delta X 1-1-\beta E C \tau-1+\varepsilon
$$

\section{Empirical Results}

This research employ following variables: per capita GDP is a proxy for economic growth; natural gas production is a proxy for the natural gas industry; labor, and export. ADF test report that data have a unit root at level. However, at first difference with trend and intercept data is stationary, and results are illustrated in Table 1.

Table 1. Results of Augmented Dickey-Fuller Test.

\begin{tabular}{lllll}
\hline Variables & ADF (t-critical) Value at 1\% significance level & ADF (t-critical) Value at 5\% significance level & T-Statistic & Probability \\
\hline DGDP & -3.548208 & -2.912631 & -6.126380 & 0.0000 \\
DGAS & -3.557472 & -2.916566 & -6.007960 & 0.0000 \\
DLABOR & -3.496960 & -4.140848 & -9.793170 & 0.0000 \\
DEXPORT & -3.568308 & -2.921175 & -3.005000 & 0.0412 \\
D(U) & -3.568308 & -2.921175 & -4.205445 & 0.0016 \\
\hline
\end{tabular}

Source: Authors, 2017

In line with formula $1 \mathrm{ECM}$ equation is as follows:

$$
\mathrm{DGDP}=\beta_{0}+\beta_{1} \mathrm{DGAS}+\beta_{2} \mathrm{DEXPORT}+\beta_{3} \mathrm{DLABOR}+\mathrm{U}_{\mathrm{t}-1}+\varepsilon
$$

Results illustrated in Table 2 show that variables are cointegrated, and they have a long-run relationship, which reveals that natural gas production, export, and labor are positively cointegrated with economic growth, and they have a long-run relationship. The residual corrects the disequilibrium of the system at $19.9 \%$ speed quarterly. In a short-run relationship, the natural gas industry has a positive impact on economic growth. At another side, export and labor are not statistically significant to impact on economic growth. Export and labor affect each other therefore an increase in export will improve labor and vice-versa.
Nonetheless, both export and labor do not have an effect on the natural gas industry. Table 3 shows results of diagnosis tests and we report that our model is stable and not serially correlated. Figure 2 reveals that ECM is stable and it is running inside the two straight lines which represent critical limits at 5\% significance level. The result of this study supports the hypothesis which states that natural gas industry and economic growth in Mozambique are cointegrated and they have a long-run relationship. This result is similar to results reported by [20] surveying OECD countries; [64] in Malaysia; and [24] in Tunisia.

\begin{tabular}{|c|c|c|c|c|}
\hline \multicolumn{5}{|c|}{ Method: Least Squares } \\
\hline \multicolumn{5}{|c|}{ Sample (adjusted): 2000Q3 2014Q4 } \\
\hline \multicolumn{5}{|c|}{ Included observations: 55 after adjustments } \\
\hline Variable & Coefficient & Std. Error & t-Statistic & Prob. \\
\hline DGAS & $1.76 \mathrm{E}-07$ & $4.25 \mathrm{E}-08$ & 4.130070 & 0.0001 \\
\hline DEXPORT & 103.1678 & 63.51507 & 1.624305 & 0.1107 \\
\hline DLABOR & 2.61E-05 & $1.64 \mathrm{E}-05$ & 1.590574 & 0.1181 \\
\hline $\mathrm{U}(-1)$ & -0.199447 & 0.059513 & -3.351295 & 0.0016 \\
\hline
\end{tabular}

Table 2. Output of ECM. 


\begin{tabular}{|c|c|c|c|c|}
\hline \multicolumn{5}{|c|}{ Method: Least Squares } \\
\hline \multicolumn{5}{|c|}{ Sample (adjusted): 2000Q3 2014Q4 } \\
\hline \multicolumn{5}{|c|}{ Included observations: 55 after adjustments } \\
\hline Variable & Coefficient & Std. Error & t-Statistic & Prob. \\
\hline DGDP(-1) & 0.321918 & 0.105402 & 3.054188 & 0.0036 \\
\hline $\mathrm{C}$ & -20.97630 & 10.33536 & -2.029567 & 0.0478 \\
\hline R-squared & 0.521777 & Mean dependent var & & 1.769455 \\
\hline Adjusted R-squared & 0.472979 & S.D. dependent var & & 95.84867 \\
\hline S.E. of regression & 69.58250 & Akaike info criterion & & 11.42557 \\
\hline Sum squared resid & 237244.5 & Schwarz criterion & & 11.64455 \\
\hline Log likelihood & -308.2032 & Hannan-Quinn criter. & & 11.51025 \\
\hline F-statistic & 10.69255 & Durbin-Watson stat & & 1.571166 \\
\hline Prob (F-statistic) & 0.000001 & & & \\
\hline
\end{tabular}

Source: Authors, 2017

Table 3. Diagnostic Tests.

\begin{tabular}{ll}
\hline Breusch-Godfrey Serial Correlation LM Test & \\
F-Statistic & $0.430812(0.6526)$ \\
Obs* R-squared & $0.995736(0.6078)$ \\
Heteroskedasticity Test: Breusch-Pagan-Godfrey & \\
F-Statistic & $1.538899(0.1952)$ \\
Obs* R-squared & $7.464519(0.1883)$ \\
Heteroskedasticity Test: ARCH & \\
F-Statistic & $0.154161(0.6962)$ \\
Obs* R-squared & $0.159724(0.6894)$ \\
\hline
\end{tabular}

Note: In parentheses is the corresponding P-value

Source: Authors, 2017

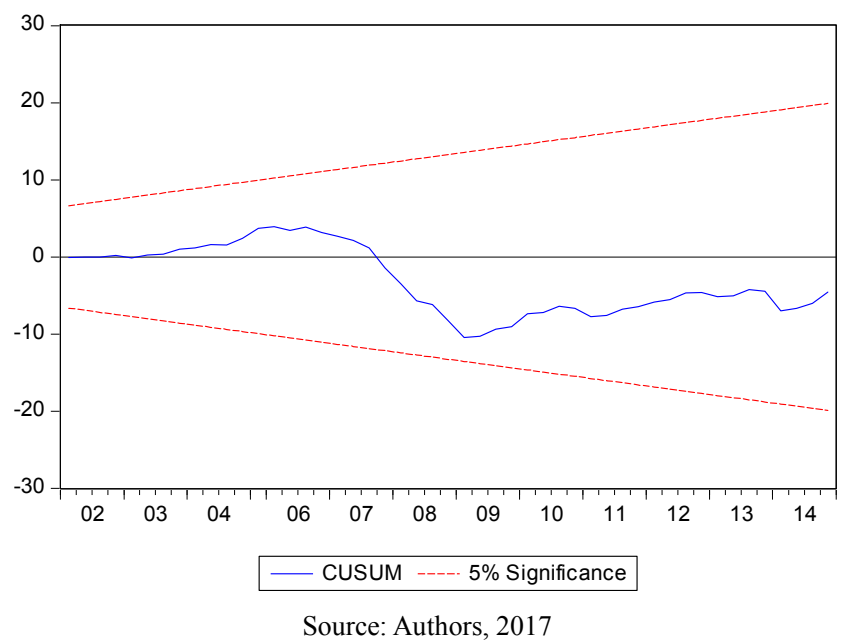

Figure 2. Recursive Estimation (CUSUM Test).

In Mozambique, the natural gas industry has a great influence on economic growth both in the short and long-run term, which means that economic growth is dependent on natural gas industry. Therefore, natural gas industry conservation policies can harm and delay economic growth. This result help for policy recommendation on natural gas industry development.

\section{Conclusion and Recommendations}

This paper investigates dynamics of the natural gas industry and economic growth in Mozambique for the period of 1999 to 2015. For this purpose, secondary times series data retrieved from Index Mundi and produced by World Bank were collected and analyzed. This study employed Error Correction model to check dynamics between natural gas industry and economic growth. Results report that the natural gas industry, export, and labor are positively cointegrated with economic growth, and they have a long-run relationship. The residual corrects the disequilibrium of the system at $19.9 \%$ speed quarterly. In a short-run relationship, there is evidence that the natural gas industry has a positive effect and it is significant to influence economic growth; however, export and labor contribution to economic growth is small. At another side, both export and labor do not have a significant effect on the natural gas industry. The implication of these results is that government should implement a growth policy for the natural gas industry because it would stimulate economic growth. The rise of economic growth will boost export and create more employment opportunities in the country. In Mozambique, the natural gas industry will experience significant dynamics with the production of natural gas in Rovuma Basin scheduled to start by 2022, and it will play a great role to raise the economic growth of Mozambique in the upcoming future. Therefore, the government should strictly observe the principle of transparency when assessing natural gas industry; not only to ensure that this natural resource will contribute significantly to economic growth, but also make sure that its exploration is sustainable. The development of natural gas industry will allow decreasing of the current high cost of oil imports and gradually reduce its dependence. This paper fills the gap in the literature on natural gas industry and economic growth nexus. Future research should focus on domestic demand and supply for natural gas; price regulation and the role of stakeholders in Rovuma Basin natural gas project, and also to check the relationship between the natural gas industry and key sectors (agriculture, industrial and services) of the Mozambique economy.

\section{References}

[1] Akinlo, Anthony Enisan (2012), How important is oil in Nigeria's Economic growth? Journal of Sustainable Development, Vol. 5, No 4.

[2] Amadeh, H. Morteza, Ghazi \& Abbasifar, Z. (2009), Causality relation between energy consumption and economic growth and employment in Iranian economy, Tahgighat-E-Eghtesadi, 44: 1-38. 
[3] Anadarko (2014), Environmental Impact Assessment report for the Liquefied Natural Gas project in Cabo Delgado, Vol. 1, Impacto \& ERM, South Africa. Retried from: Mzlng.com/content/documents/MZLNG/EIA/volume1/Englis $\mathrm{h} / \mathrm{Vol} 1$ _front_pages_NTS_LNG_Final_EIA_sept_2014_Eng.pdf

[4] Anshasy, Amany A. \& Katsaiti, Marina-Selini (2013), Natural resource and fiscal performance: does governance matter? Journal of Macroeconomics 37: 285-298.

[5] Apergis, Nicholas \& Payne, James (2010), Natural gas consumption and economic growth: a panel investigation of 67 countries, Applied Energy, 87: 2759-2763.

[6] Aqeel, Anjum \& Butt, Mohammad (2001), The relationship between Energy consumption and economic growth in Pakistan, Asia-Pacific Development journal, Vol. 8, No. 2.

[7] Arman S. A. \& Zare R. (2005) An investigation of Granger causality relationship between energy consumption \& economic growth in Iran (1967-2002), Iranian Economic Research, Vol. 7, No 24: 117-144.

[8] Asghar, Zahid (2008), Energy-GDP relationship: a causal analysis for the five countries of South Asia, Applied Econometrics and International Development, 1: 167-180.

[9] Asgharpour, Hossein, Behboudi D. \& Ghazvinian, M. H. (2009), Structural Break: the case of gas consumption and economic growth in Iran, Quarterly Energy Economics Review, Vol. 5, No 19: 105-121.

[10] Asteriou, Dimitrios (2006), Applied Econometrics, A modern Approach using Eviews and Microfit, Palgrave Macmillan.

[11] Biggs, Tyler (2012), Mozambique's coming natural resource boom: expectations, vulnerabilities, and policies for successful management, CTA/USAID, Maputo.

[12] Bildirici, Melike \& Bakirtas, Tahsin (2014), The relationship among oil, natural gas and coal consumption and economic growth in BRICTS (Brazil, Russian, India, China, Turkey and South Africa) countries, Energy 65: 134-144.

[13] Bucuane, Aurelio \& Mulder, Peter (2008), Expanding exploitation of natural resources in Mozambique: will it be a blessing or a curse? Reflection on economic questions, IESE, Maputo.

[14] Cabral, Renata Fonseca (2013), estimativa econometrica das elasticidades renda e preço na demanda por gas natural para o sector industrial brasileiro, São Paulo, thesis. Retrieved from: http://www.afd.fr/lang/pt/home/pays/afrique/geo-

afr/mozambique/projets-mz/infra/energie2/gaz-naturel-pandetemane_1

[15] Campos, Adriana Fiorotti, Da Silva, Neilton Fidelis \& Perreira, Marcio Giannini (2016), A review of Brasilian natural gas industry: challenges and strategies, Renewable and sustainable Energy reviews.

[16] Cheng, Benjamin \& Lai, Tin Wei (1997), An investigation of co-integration and causality between energy consumption and economic activity in Taiwan, Journal of Energy Economics 19: 435-444.

[17] Collier, Paul (2007), The bottom billion, why the poorest countries are failing and what can be done about it, Oxford University Press, New York.

[18] Daniele, Vittorio (2011), Natural resources and economic growth: a curse or a blessing? Rivista Italiana degli
Economist, Vol. 16, No 3, pp 507-528.

[19] Demko, Iryna (2010), Nexus of natural gas consumption and regional economic growth in Ukraine policy implication, Kyiv School of Economics, Thesis submitted for the degree of MA in Economics. Retrieved from: www.kse.org.ua/uploads/thesis_demko_final\%20version.pdf

[20] Destek, Mehmet A. (2016), Natural gas consumption and economic growth: panel evidence from OECD countries, Energy 114: 1007-1015.

[21] Economist Intelligence Unit. Retrieved from: www.EIU/mozambiqueeconomicandpoliticaloutlook/121209

[22] Ekpulu G. A., Donwa, P. A. \& Mgbame, C. O (2015), Economic growth: oil and gas contributions, Sci-Afric Research Journal of Accounting and Monetary Policy, Vol. 1 (2), pp 102-108.

[23] Ewing, Bradley T., Sari, Ramazan \& Soytas, Ugur (2007), Disaggregate energy consumption and industrial output in the United States, Energy Policy, 35: 1274-1281.

[24] Farhani, Sahbi, Shahbaz, Muhammad, Arouri, Mohamed, \& Teulon, Frédéric (2014), The role of natural gas consumption and trade in Tunisia's output, Energy Policy, 66: 677-684.

[25] Frühauf, Anne (2014), Mozambique's LNG revolution: a political risk outlook for the Rovuma LNG ventures, The Oxford Institute for Energy studies, Oxford University.

[26] Furuoka, Fumitaka (2016), Natural gas consumption and economic development in China and Japan: an empirical examination of the Asian context, Renewable and Sustainable Energy Reviews 56: 100-115.

[27] Gqada, Ichumile (2013), a boom for whom? Mozambique's Natural Gas and the New Development Opportunity, South African Institute of International Affairs.

[28] Heidari, Hassan, Katircioglu, Turan Salih \& Saeidpour, Lesyan (2013), Natural gas consumption and economic growth: are we ready to natural gas price liberalization in Iran? Energy Policy, 63: 638-645.

[29] Hofmann, Katharina \& Martins, Adrian de Souza (2012), Descoberta de Recursos Naturais em Moçambique: Riquesa para poucos ou um meio de sair da pobreza? Friedrich - Ebert - Stiftung Mozambique. Retrieved from: http:/cesab.edu.mz/wp-content/uploads-Cesab.pdf.

[30] Hu, Jin-Li, \& Lin, Cheng-Hsun (2008), Disaggregated energy consumption and GDP in Taiwan: a threshold cointegration analysis, Energy Economics, 30: 2342-2358.

[31] Index Mundi, 2017; www.indexmundi.com

[32] Kemp, Rene \& Parto, Saeed (1995), Governance for sustainable development: moving from theory to practice, Int. J. Sustainable Development, Vol. 8, Nos 1/2, MERIT, Maastricht University.

[33] Khan, Muhammad Arshad \& Ahmed, Usman (2009), Energy demand in Pakistan: a disaggregate analysis, the Pakistan Development Review, 4: 1-27.

[34] Kum, Hakan, Ocal, Oguz \& Aslan, Alper (2012), The relationship among natural gas energy consumption, capital and economic growth: a bootstrap-corrected causality test from G-7 countries, Renewable and Sustainable Energy Reviews, 16: 2361-2365. 
[35] Lee, Chien-Chiang \& Chang, Chun-Ping (2005), Structural breaks, energy consumption and economic growth revisited: Evidence from Taiwan, Energy Economics, 27: 857-872.

[36] Lim H. J., \& Yoo, S-H (2012) Natural gas consumption and Economic growth in Korea: a causality analysis, Energy sources, Part B: Economics, Planning, and Policy, 7: 2, 169176.

[37] Lotfalipour, Mohammad Reza, Falahi, Mohammad Ali \& Ashena Malihe (2010), Economic growth, $\mathrm{CO}_{2}$ emissions, and fossil fuels consumption in Iran, Energy, 35: 5115-5120.

[38] Melina, Giovanni \& Xiong, Yi (2013), Natural gas, public investment and Debt sustainability in Mozambique, IMF working paper, New York.

[39] Ministry of Energy and Mineral Resources of Mozambique, 2015; www.mireme.gov.mz

[40] Mithá, Omar (2015), Desenvolvimento da Indústria de Hidrocarbonetos em Moçambique: Perspectivas de impacto, Conferência sobre ganhos do Estado na Exploração de Hidrocarbonetos, Maputo.

[41] Moshi, Humphrey P. B. (2013), Opportunities and challenges for the extraction of natural gas in Tanzania: the imperative of adequate preparedness, Economic, and Social Research Foundation.

[42] Mozambique National Hydrocarbon Company; 2016, www.enh.gov.mz

[43] Mozambique National Petroleum Institute, 2014; www.inp.gov.mz

[44] Namuyondo, Esther (2014), Sustainability and Oil Exploration in Uganda - the case of Uganda's Albertine Region, Master Thesis, Aalborg University.

[45] Oduyoye, A. O., Aderinto, E. R. \& Ejumedia P. E (2013), Energy consumption and economic growth revisited: empirical evidence for Nigeria, $6^{\text {th }}$ NAEE/IAEE International Conference, April 22-23, Lagos, Nigeria. Retrieved from: http://www.slideserve.com/maxima/energy-consumption-andeconomic-growth-revisited-empirical-evidence-for-nigeria

[46] Onakoya, Adegbemi Babatunde, Onakoya, Adegbemi Olatunde, Jimi-Salami, Olalekan Adejuwon \& Odelairo, Babatunde Omoniyi (2013), Energy consumption and Nigerian economic growth: an empirical analysis, European Scientific journal, Vol. 9, No 4.

[47] Payne, J. E. (2011) US disaggregate fossil fuel consumption and real GDP: an empirical note, Energy Sources, Part B: Economics, Planning and Policy; 6: 63-68.

[48] Pirlogea, Corina, \& Cicea, Claudiu (2012), Econometric perspective of the energy consumption and economic growth in European Union, Renewable and Sustainable Reviews, 16: $5718-5726$.

[49] Rafindadi, Abdulkadir Abdulrashid, \& Ozturk, Ilhan (2015), Natural gas consumption and economic growth nexus: is the $10^{\text {th }}$ Malaysian Plan attainable within the limits of its resource? Renewable and Sustainable Energy Reviews; 49: 1221-1232.

[50] Reynolds, Douglas B. \& Kolodziej, Marek (2008), Former Soviet Union oil production and GDP decline: Granger causality and the multi-cycle Hubbert curve, Energy
Economics, 30: 271-289.

[51] Robin Best (2008), An introduction to Error Correction Model, Oxford Spring school of quantitative methods in social research. Retrieved from: https://wenku.baidu.com/view/4c5edece1 eb91a37f1115cba.ht $\mathrm{ml}$

[52] Rolo, Jose Manuel, \& Tschanze, Adelia Fereira (2008), Moçambique na geoeconomia do gas natural. Retrieved from: http://www.scielo.nec.pt/pdf/egg/v13n1/v13n1a05.pdf

[53] Rosser, Andrew (2006), The political economy of the resource curse: a literature survey. IDS Working Paper 268. Retrieved from: www.ids.uk/ids/bookshop

[54] Saidi, Kais \&Hammani, Sami (2014), Energy consumption and economic growth nexus: empirical evidence from Tunisia, American Journal of Energy Research, Vol. 2, No 4, 81-89.

[55] Sari, Ramazan, Ewing, Bradley T. \& Soytas, Ugur (2008), The relationship between disaggregate energy consumption and industrial production in the United States: an ARDL approach, Energy Economics, 30: 2302-2313.

[56] Sasol Annual Review, 2014. Retrieved from: sasol.com/extras/annual-integrated-report.

[57] Selemane, Tomás (2009), Alguns desafios da indústria extractiva em Moçambique, CIP, Maputo.

[58] Shahbaz, Muhammad, Arouri, Mohamed, \& Teulon, Frédéric (2014), Short and long-run relationships between natural gas consumption and economic growth: evidence from Pakistan, Economic Modelling, 41: 219-226.

[59] Shahbaz, Muhammad, Farhani, Sahbi \& Rahman, Mohammad Mafizur (2013b), Natural gas consumption and Economic growth nexus: the role of exports, capital, and labor in France, Munich personal Repec archive.

[60] Shahbaz, Muhammad, Lean, Hooi Hooi \& Farooq, Abdul (2013a), Natural gas consumption and economic growth in Pakistan, Renewable and Sustainable Energy Reviews, 18: 87-94.

[61] Siddiqui, Rehana (2004), Energy and Economic Growth in Pakistan, the Pakistan Development Review, 43, 2: 175-200.

[62] Silva, Teresa, (2013), Exploração de Recursos Energéticos e Ameaças Futuras, Cesab: Bragança. Retrieved from: http:/cesab.edu.mz/wp-content/uploads-Cesab.pdf

[63] Solarin, Sakiru \& Ozturk, Ilhan (2016), The relationship between natural gas consumption and economic growth in OPEC members, Renewable and Sustainable Energy Reviews, 58: $1348-1356$.

[64] Solarin, Sakiru Adebola \& Shahbaz, Muhammad (2015), Natural gas consumption and economic growth: the role of foreign direct investment, capital formation and trade openness in Malaysia, Renewable and Sustainable Energy Reviews, 42: 835-845.

[65] Sousa, Francisco Jose Rocha de (2010), O sector do gás natural no mundo, Nota técnica. Retrieved from: http://www2.camara.leg.br/documentos-epesquisa/publicacoes/estnottec/areas-daconte/tema16/2009_11105.pdf

[66] Susic, Vukasin \& Zivkovic, Jelena (2012), Energy resources and global geopolitical processes, Factas Universitatis, Economics and Organization, Vol. 9, No 1, 39-52. 
[67] The Economist (2012), an unconventional bonanza, Special report on natural gas.

[68] World Bank, 2017. Retrieved from: www.worldbank.org/en/country/mozambique/overview
[69] Yang, Hao-Yen (2000), A note on the causal relationship between energy and GDP in Taiwan, Journal of Energy Economics 22: 309-317.

[70] Zamani, Mehrzad (2007), Energy consumption and economic activities in Iran, Energy Economics, 29: 1135-1140. 